\title{
possible connections between the montessori method and philosophy for children
}

\author{
mariangela scarpini ${ }^{1}$ \\ università degli studi di bologna, italy \\ orcid id: https:/ / orcid.org/0000-0003-4743-3906
}

\begin{abstract}
This paper aims to focus on certain aspects of two education methods: one initiated in the first half of the twentieth century by Maria Montessori, and the other in the second half of that century by Matthew Lipman. The aim - neither comparative nor analytical - is to shed light on the connections and, more specifically, the elements of the Montessori Method that reflect on Lipman's proposal. The question this paper aims to answer is: can P4C find fertile ground in schools that apply the Montessori Method? The paper will focus, among other elements, on the importance of giving space for thinking experience from childhood on, and on the recognition of the value of childhood. Both Lipman and Montessori have systematically observed children of different ages - the former in the first half, the latter in the second half of the twentieth century. Both recognized, gave value, and focused their scientific contributions on children's ability to think and express their thoughts through languages (purposely in the plural form). As educational researchers and professionals know, children have the ability to think, but such ability has not always been (and still isn't) considered to exist. Even when it is evoked in words, educational choices and proposals seem-even today--to express mistrust towards children's thought. The two mentioned authors have repeatedly highlighted the importance of an essential right: the right to think and to be given a space - even as children - to exercise thinking with others. In particular, both authors - though envisaging different educational paths - identified the same categories functional to exercising thinking. Their interconnection may guide the actions of teachers, educators, and learning process experts. In fact, P4C might play a role in educational contexts in which the class is already considered a community of inquiry, in which the teacher is assigned the same role as a facilitator.
\end{abstract}

keywords: montessori; lipman; right to think; creative environment; new teacher.

\section{posibles conexiones entre el método montessori y la filosofía para niños (p4c)}

\section{resumen}

Este artículo tiene como objetivo centrarse en ciertos aspectos de dos métodos de educación: uno iniciado en la primera mitad del siglo XX por Maria Montessori, y el otro en la segunda mitad del siglo XX por Matthew Lipman. El objetivo, ni comparativo ni analítico, es arrojar luz sobre las conexiones y, más específicamente, los elementos del Método Montessori que se reflejan en la propuesta de Lipman. La pregunta que este texto pretende responder es: ¿puede P4C encontrar terreno fértil en las escuelas que aplican el Método Montessori? El texto se centrará, entre otros elementos: en el reconocimiento de la importancia de dar espacio a la experiencia de pensamiento desde la infancia y de reconocer el valor de la infancia. Tanto Lipman como Montessori han observado

\footnotetext{
${ }^{1}$ Mariangela Scarpini; PhD, Department of Education Studies "Giovanni Maria Bertin", Alma Mater Studiorum - University of Bologna. P4C Teacher Expert and Teacher at Montessori Schools E-mail: mariangela.scarpini@unibo.it
} 
sistemáticamente a niños de diferentes edades: el primero en la segunda mitad y la segunda en la primera mitad del siglo XX. Ambos caracterizaron, dieron valor y centraron sus contribuciones científicas en la capacidad de los niños para pensar y expresar sus pensamientos a través de lenguajes (a propósito en forma plural). Como saben los investigadores y profesionales de la educación, los niños tienen la capacidad de pensar, pero esa capacidad no siempre se ha considerado (todavía no es considerada). Incluso cuando se evoca con palabras, las opciones y propuestas educativas parecen, aún hoy, expresar desconfianza hacia el pensamiento de los niños. Los dos autores mencionados han subrayado en repetidas ocasiones la importancia de un derecho esencial: el derecho a pensar y a tener un espacio, incluso como niños, para ejercitar el pensamiento con los demás. En particular, ambos autores, aunque previeron diferentes caminos educativos, identificaron las mismas categorías funcionales para ejercitar el pensamiento. Su interconexión puede guiar las acciones de maestros, educadores y expertos en procesos de aprendizaje. De hecho, P4C podría desempeñar un papel en contextos educativos en los que la clase ya se considera una comunidad de investigación, en la que al profesor se le asigna el mismo papel que un facilitador.

palabras clave: montessori; lipman; derecho a pensar; ambiente creativo; nuevo profesor.

\section{possíveis conexões entre o método montessori e a filosofia para crianças}

\section{resumo}

Este artigo tem como objetivo focalizar certos aspectos de dois métodos de ensino: um iniciado na primeira metade do século XX por Maria Montessori e o outro na segunda metade desse século por Matthew Lipman. O objetivo - nem comparativo nem analítico é esclarecer as conexões e, mais especificamente, os elementos do Método Montessori que refletem na proposta de Lipman. A pergunta que este artigo pretende responder é: o FpC pode encontrar um terreno fértil nas escolas que aplicam o Método Montessori? O artigo enfocará, entre outros elementos: a importância de dar espaço à experiência de pensar desde a infância e o reconhecimento do valor da infância. Tanto Lipman quanto Montessori observaram sistematicamente crianças de diferentes idades - o primeiro na primeira metade, a segunda na segunda metade do século XX. Ambos caracterizaram, deram valor e concentraram suas contribuições científicas na capacidade das crianças de pensar e expressar seus pensamentos através de línguas (propositadamente na forma plural). Como pesquisadores e profissionais de educação sabem, as crianças têm a capacidade de pensar, mas essa capacidade nem sempre foi (ainda não é) considerada existente. Mesmo quando evocada em palavras, as escolhas e propostas educacionais parecem - ainda hoje - expressar desconfiança em relação ao pensamento das crianças. Os dois autores mencionados enfatizaram repetidamente a importância de um direito essencial: o direito de pensar e de ter um espaço - mesmo quando criança - para exercitar o pensamento com os outros. Em particular, ambos os autores - apesar de contemplarem diferentes caminhos educacionais - identificaram as mesmas categorias funcionais para o exercício do pensamento. Sua interconexão pode orientar as ações de professores, educadores e especialistas em processos de aprendizagem. De fato, a FpC pode desempenhar um papel em contextos educacionais nos quais a classe já é considerada uma comunidade de investigação, na qual o professor recebe o mesmo papel de facilitador.

palavras-chave: montessori; lipman; direito de pensar; ambiente criativo; novo professor. 


\section{possible connections between the montessori method and philosophy for} children

\section{introduction}

When have we ever thought about thought? Matthew Lipman Why shouldn't a child be able to exercise philosophy? Maria Montessori

\section{1900s}

The past century - thanks to an interesting political, social, and pedagogical discussion that has contributed to promote renewed interpretations of childhood has opened the door to ambivalent scenarios: on one hand, promises and rewards (a large number of laws, undersigned internationally, to safeguard children and their rights); on the other hand, the denial of rights.

Montessori entered this 1900s cultural setting perfectly, even anticipating more contemporary appeals. Montessori took a stand in favor of childhood on two fronts: through the spread of her method within academic institutions, and in the fight for children's rights.

Montessori began her book The Child in the Family with a chapter titled "The white page". In the latter, she speaks of the child as (Montessori, 2000, 12):

An important personality in itself - and with different needs to satisfy compared to the adult, in order to reach the paramount goals of life - had never been considered before. The child was seen as a weak being that required the help of an adult, if not a human personality without rights and oppressed by the adult. The child [...] is still an unknown entity. There is a white page concerning it in the history of mankind. Our aim is to start filling that very white page).

Montessori, a revolutionary woman, defines children as "white pages" on which adults may write their conditioning; the child is not an empty flowerpot to fill or a piece of clay to model. She refers, instead, to the white page in human history on which children's rights have never been written.

Along the same lines, in 1951 she made a plea directly to UNESCO, highlighting how the great Universal Declaration of Human Rights ignored a citizen, among others: the child. 
possible connections between the montessori method and philosophy for children

Montessori highlighted how children - in general and in terms of rights were almost completely inexistent in the Universal Declaration of Human Rights, and, when considered, they were only seen as weak individuals, needing care and assistance.

In the thirty articles assessing the most fundamental human rights, the little ones are only considered in the second paragraph of Article 25: "Motherhood and childhood are entitled to special care and assistance". Which is not much, in that the assistance mentioned, though "special", falls under the type of assistance foreseen in case of disability, poverty, or old age. Children themselves are not considered. They continue to be seen as weak human beings, insignificant to the destiny of mankind: attachments that lie purely in the hands of their mother, or in nature.

Maria Montessori contests the world of her (and our) days, stating that often children live in a world that is not their own, not child-size, in which things and people are neither fitted to them nor belong to them: living in such a world does not allow children to express what they truly know how to do. The child has a fundamental function in human development. If the dignity of manual laborers is recognized, then the dignity of workers producing humans shall also be recognized. Based upon such an affirmation of dignity, we shall ensure the child's right and freedom to grow.

As long as childhood is not interpreted with the potential it bears, it will never be fully and completely seen nor considered. Being aware of this calls for responsibility in terms of education and care that the adult world must have in its entirety.

\section{2. montessori and lipman in defense of children's rights, including the right to} think

Whilst in the first half of the 1900s Montessori set the basis for modern conquers or results yet to be achieved, in the second half of the same century, Lipman - in the U.S. - underlined the importance of educating thought since the early years of life: he recognized children as competent in terms of thought, as 
long as the educator/the adult knows how to use and listen to the different ways the children express their inner world. I shall return to this at a later stage.

Lipman believed that exercising thought was not only legitimate - given children's ability to think - but necessary: in the 1970s, as he worked as a Logic professor at Columbia University, Lipman observed the need for students to exercise their thought processes long before the beginning of their university career, namely as children. This was the start of the Philosophy for Children experience.

By means of Philosophy for Children - currently supported by the UNESCO Division of Philosophy (Goucha, 2007) due to its correspondence to the promotion of WHO life skills and soft skills - he proposed a pathway not so much with the purpose of learning philosophy, but one intended for exercising philosophy - or rather philosophizing.

Along the same lines, Montessori had already posed an interesting doubt on the matter: "why shouldn't a child be able to exercise philosophy?" (Montessori, 2016, 100). Montessori made the skills and the value of children the focal and starting point of her work, always underlining that at the basis of the system she created there is always, inextricably, "the discovery of the child": it is interesting to notice how, ever since the first appearance of her method, Montessori highlighted a considerable negation of childhood skills and rights.

Starting from the abundance of standards and national/international research pinpointing the effort made by the adult world to recognize the skills and rights specific to children, we may hereby observe how certain organizational proposals - even targeted towards children - tend to encourage performances related to summary thinking and winning - even in terms of competition - and more concentrated on the product rather than on the growth and/or learning process.

We interrogate ourselves - through Montessori and Lipman - on the possibility to teach children how to interact with each other in ways focused on respective care: to ask, ask themselves, and be asked questions; to find answers together and think together! In order to find an answer to such interrogative, I 
possible connections between the montessori method and philosophy for children

hereby reiterate the perspectives of the two abovementioned masters: the Montessori Method (Montessori, 2007) and Philosophy for Children (Lipman, 2005). Both educational paths contemplate education to complex thought as a possible and necessary element.

Montessori and Lipman lived and worked in completely different historical eras. Given that I acknowledge the dissimilar conditions in which the reflections of the two authors were born, I intend - in this article - to focus on certain key elements that connect the two methods. In particular, we may identify certain functional pedagogic tools that we shall outline in the following paragraph.

\section{3. montessori and lipman: common categories to re-think educational paths for}

\section{thought exercise, starting in the childhood phase}

As she called upon the need to exercise thought starting as a child, Montessori came to ask herself a question, almost rhetorical: "why shouldn't a child be able to exercise philosophy?" (Montessori, 2016, 100). Some thirty years later, on the other side of the Atlantic, inspired by the same observation on childhood thought skills, Lipman and his collaborators (see: Lipman, Sharp, Oscanyan, 1977; Lipman, 2003; Lipman, 2008) asked themselves similar questions. They created Philosophy for Children, which envisioned the possibility to exercise philosophy in a classroom (Lipman, 2003, 139):

Philosophizing in the classroom should allow an exchange of ideas, perspectives, and issues, along with the cooperative search for possible solutions. Certainly, this is a long-term perspective and requires everyday practice, throughout which those involved get used to expressing their positions and justifying them through discussion and offering plausible and embraceable reasons.

Among the identifiable interconnections between the theories of Montessori and Lipman, that the present article does not have the ambition to present, I shall attempt to consider some of the founding principles of Philosophy for Children that show a link with the Montessori Method. The identified elements may be especially interesting for those involved in current research on the Montessori Method or for teachers choosing to work using such method.

Let us begin by expanding on the ones already partially introduced: The representation of children, Contexts as protective and creative environments, 
Society by cohesion and Community of Inquiry, and The new teacher and the Teacher in $\mathrm{P} 4 \mathrm{C}$.

\section{1 the representation of childhood}

Some may ask themselves whether exercising thought since childhood really makes sense: aren't they just children? But little boys and girls think indeed. I am aware that the following seems a rather ridiculous and plain statement to make, but nevertheless I observe that time and space for thought expression and exercise in Italian schools - for example - is not clearly specified in any standard, and is purely left to the academic planning of teachers, who unfortunately - in most cases - choose lecture-based, transmission teaching. In fact, children are viewed by both Montessori and Lipman as:

- active individuals: children able to learn and define the world, both discovering it through their senses and investigating it through academic contents and making discoveries;

- independent individuals: already in the early years, both through behavior and through explicit indications given to the adult: "help me do it on my own" or "I'll do it!". One might interpret the utterance on different levels, and re-read it as "help me think on my own" or "help me think with you", or even "help me think as I build empathy with you";

The child has to acquire physical independence, independence of choice, and independent thought. Montessori promoted methods involving a plethora of thought exercises on different levels. By using diversified tools and overcoming the mind-body dualism, she highlighted that children think when they explore the world using their senses, when they question reality (the Other and the Self), or when they investigate situations.

Montessori describes the child as "a philosopher that thinks with the hands" (Regni, 2006, 97), and the entire Montessorian setup seems to underlie, as an end purpose, thought exercise. She described competent individuals as children with special skills related to each growth phase - as long as their surrounding environment (the physical and material environment, but not only) is made to measure for them in terms of organization and activity design, as well as the relationship level. Among the highlighted skills, there is of course thinking and thinking together -, although for such process to occur, the child must be 
possible connections between the montessori method and philosophy for children

offered a protective, welcoming, and creative environment, able to embrace the reflections, questions, (multiple) languages specific to children.

\section{2 contexts}

We thus move on to a second point of intersection between the two educational proposals identified: the construction of the environment. In her experience, Montessori started giving priority to context design upon creation of her first Children's House. Children proved to be competent, skillful, and able, as they were placed in the condition to work independently. They did not need to ask for help to pick up an object, or cry until someone poured them a glass of water: objects were made to measure for them. Quite simply, the first thing Montessori did in San Lorenzo (the neighborhood in Rome hosting the first-ever Children's House) was sawing the legs of chairs and desks and creating an environment that facilitated independence. It was only the beginning.

But, when we speak about an environment, we don't only refer to child-size chairs and desks - that would be reductive. I do not mean that, simply, desks were laid out as group pods to facilitate co-construction of knowledge. It is part of the picture, but not the full picture. The physical aspects are essential, but at the same time the aspects related to the emotional and relationship environment are also instrumental. The environment presented by both Montessori and Lipman is, indeed, a safe and at the same time creative context, which fears not the mistake in itself, but rather accepts the risk to commit a mistake, and for the child to use it to its benefit, as a bringer of new creations (Weinstein, 2016). What can be created as a consequence of a mistake?

Upon acknowledging a mistake, what can be understood concerning our lack of knowledge? Montessori overturned the concept of mistake in itself, defining it as a friend: "So the best thing is to become friendly with the error and then it will not frighten us anymore, but will be a friendly person living among us and will perform its task, because it has one." (Montessori, 1948, 184) She also names such the functional aspect within the learning and construction process a Gentleman: “No matter where we look, we always find Gentleman Error! If we set out on the path towards perfection, we must look carefully at error, because 
perfection will come by correcting it. We should use a light to show the error. We must know there is error as there is life" (Montessori, 1948, 184).

The environment must acknowledge and promote the creative aspects of error and must consequently be designed in an aesthetic and attractive manner, "made to measure" for the child. It shall be creative and safe on different levels, especially in terms of relationships. In fact, just like Montessori, Lipman promoted the decorum and environmental care aspects, but also emphasized additional, fundamental elements: “The decorative adjustments are nevertheless not essential, and a large number of teachers work successfully in basic contexts, simply making sure that the children feel and know they are accepted, respected, and cared for." (Lipman, 2003)

Being accepted, respected, and cared for. This makes an environment educational, according to Lipman and according to Weinstein We may thus define the context as a "safe creative environment": an environment that, by providing certainties, allows the subjects to trust - both themselves and the context - and become protagonists of a conversation with potential and limits (their own, and of the world). But the environment shall not only be protective; it must at the same time spark creativity and fearlessness of the mistake in itself and the risks of facing it, moreover using it to one's advantage as a harbinger of new creations. What can be created from error? What can be understood of one's shortcomings? This is how the creation of a safe environment takes form, with its ability to effectively embrace the thoughts of little boys and girls and to transform their limits into resources, to be used to build and investigate again.

The environment in itself may be considered in the scope of two fundamental and functional implications to the topic in concern. On one hand, an environment stimulating heuristic processes from a perspective we may define as disciplinary and content-based; it is with this element that interactions between the individual and the world - meant as the privileged interlocutor to which ask questions and from which to initiate discovery-based paths. On the other hand, an environment distinguished by positivity, open to dialogue and to each and everyone's originality, in which children may express themselves and ask their 
possible connections between the montessori method and philosophy for children

own questions; children interrogate themselves and interrogate others when the experience the relationship with effective interlocutors, able to reflect and reformulate their question and/or their thought process, and able to build a nonrepressive, stimulating environment in which little boys and girls may feel complete and accepted for both their existing and potential capabilities.

\section{3. society by cohesion and community of inquiry}

Based upon the concept above, I shall move forward in identifying the third common element of the two educational proposals: redefining the concept of a group (individuals of the same or different age group or a class) as a Society by Cohesion-Community of Inquiry in which children may exercise thought together and experiment the value of discussion.

In Philosophy for Children, the concept of class is interpreted as a community, and more specifically a Community of Inquiry. Of course, the two pedagogic tools may not be overlapped, but their common denominator is the centralization of the relationship between individuals as a tool for construction and co-construction of discovery.

Similarly, in the eyes of Montessori the class is not simply a set of individuals or a Group of children sharing the same spaces and activities although it may seem this way upon superficially reviewing her early (and, perhaps, most popular) essays. Instead, in a cohesion-based society - as the term itself hints - children are oriented towards a common goal that keeps them together, close-knit, and with a shared sense of respect and community. The class is not seen as a set of individuals performing perhaps the same activity on their own, but as a group that builds its shared horizon of sense and knowledge together. In the Community of Inquiry (meant as, in particular, the philosophy Community of Inquiry) each child is the active protagonist of a research path along which collective and individual thought travel together.

The comparison between the different positions expressed by each community member is made possible through discussion, which in turn allows the facilitation of cooperation and a critical, respectful approach to ideas and 
opinions. The members investigate free of any superficiality, also accepting puzzlement and disorientation, which are functional to thought progress: just like when misbalance is necessary to reach balance in learning how to walk, in a Community of Inquiry every moment of upset, confusion, or disorientation seems to be quite effective, or even necessary, to reach a new point of view.

Within a Community of Inquiry, children also tweak their ability to present non-accusatory evaluations in which a distinction is made between the object of their evaluation (i.e. the concept expressed or the wrongfulness of an argument) and the subject comprising their point of view.

Likewise, in the paragraph titled "Society by Cohesion", Montessori underlined that "[the social coexistence of free experiences led to the fact that] these children felt and acted as a group. They really formed a society of children, united by a mysterious bond, and acted as one body. This bond was formed by a common sentiment felt by each individual. Although they were 'independent individuals'" (Montessori, 1948, 172).

One criticism to Montessori concerns the frequency with which children work individually. At first sight, this may appear to contrast with the idea of Community of Inquiry. In the Montessori method, elements including unity and collective construction of knowledge, as well as exploration of the world, branch from the ability to feel part of a group though working independently. Montessori underlined the difference there is between doing the same exact activity independently, and doing different things but feeling part of a group. Upon observing classes in which children all perform the same activity - completing a worksheet, for instance - but screened from one another (for example, one may witness scenes of pencil-case barricades built to avoid the seatmate from copying or looking at the other's work even not during testing!): I ask myself if it is an illusion; if having each of our students do the same activities doesn't hide a more pronounced form of individualism compared to making them perform different activities whilst feeling part of a whole. It would be interesting for everyone to observe a class/section of a Montessori school in person, but given this is not always possible, I believe observing the relationships and industriousness of 
possible connections between the montessori method and philosophy for children

children at school through a documentary is also a valid option. I may suggest a short documentary ${ }^{2}$ produced by the multimedia lab (MELA) of the Department of Education Studies at the University of Bologna and filmed at the Casa dei Bambini (children's home) of Chiaravalle (Ancona) in which I suggest to concentrate on the connections linking the children together: on their exchanges of looks, on their actions (actions concealing thought, although in the clip perhaps it is not strictly a philosophical thought), and their way of performing different tasks but feeling part of a group.

A community built as such may also afford to deal with difficult situations and linger on certain doubts... together. As Montessori stated: "Let me make a bold statement: we need to offer them the philosophy of things" (Montessori, 2007, pg. 195).

It is a context that, when orderly and structured, offers a safe base to avoid puzzlement and unwanted reactions. A context that listens and welcomes thoughts and questions. On November 27, 2015, here in Bologna, my colleagues and I have experienced a day of research and workshops concerning the P4C topic; the event was named "Per un'infanzia che interroga e si interroga" (for children who ask questions and ask themselves questions). Indeed, little boys and girls ask questions and ask themselves questions, but manage to come into contact with them and formulate them only within their abilities (in the multiple languages peculiar to children, from the use of limbs to the use of words), thus only if there is a context that is capable of greeting them, and as long as adults above all - are able to not brush off the questions using common, repeated, rushed answers, as rushed as a way of thinking that searches for easy, comfortable solutions. Therefore, they may experience the questions given that there exists a community performing collective research, and able to say, "let's think about this question together".

To greet questions and reflections implies, as mentioned, a concept of the classroom being a Community of Inquiry, in which confrontation (meant as the

$2 \quad$ Fully $\quad$ available 2 at: TK1\&index $=2 \& \mathrm{t}=2 \mathrm{~s}$ 
opportunity for exchange of ideas and enrichment of thoughts) with different ways of interpreting the world, and different, numerous logical and cognitive trajectories to do so is possible. It is within this form of community that the children are given the chance for a broad-spectrum "intensive training" on the acceptance of others as bearers of perspectives even antipodal to their own, on the methods of creative and nonviolent communication, and on "lingering in doubt" and "preserving questions" (Rilke, 1989).

In relation to the above, we may read some of the questions formulated by groups of $3^{\text {rd }}, 4^{\text {th }}$, and $5^{\text {th }}$-graders at the Montessori school in Chiaravalle (Ancona) during a $\mathrm{P} 4 \mathrm{C}$ session:

Is it possible not to pollute? M., 9 years old

How would we feel inside another's body? F., 10 years old

Why do some people tend to listen to other people's judgement and give up certain things (objects, people, pets, thoughts, opinions...)? R., 9 years old

Do aliens exist? S., 9 years old

Why does war exist? Who invented it? L., 9 years old

Why do we live on Earth? I., 9 years old

What is thought? N., 9 years old

Why do we think? How is a thought born? S., 10 years old

Are we the only living beings in the universe? G., 10 years old

How do we exist? K., 10 years old

Why hasn't God wiped us out if he knew we would have ruined the world? R., 10 years old

Why can't I ever stop thinking? S., 8 years old

Why are languages different? [NAME?]

Why does school exist? A., 9 years old

Why do we live? F., 10 years old

If a person were blind, deaf, and mute, how would he/she communicate? L., 9 years old (so much cognitive decentering in this question!)

Why do I think I don't know anything, but I do? P., 8 years old

How many drops are there in the sea? S., 9 years old

Why do people ask themselves so many questions? D., 9 years old

Why do certain people feel less important than others? E., 11 years old

How can people know if they are good at the sport or activity they practice? For example, when they have a race and are afraid to perform an exercise, how do they know if they are performing it well? M., 10 years old

If a person says they don't know anything, could they instead know lots of things? Oppositely, if a person says they know lots of things, could they not know anything? M., 9 years old

In a community that accepts questions and appreciates them as the starting points for an investigation, they take on a value even greater than that of answers. Whilst at times answers may take different directions, such community acknowledges to have started with a bonding element: the same question. 
possible connections between the montessori method and philosophy for children

The fourth and final element of our discussion is: the "new teacher". The guarantor for the creation of the Community of Inquiry and the society by cohesion is the so-called "Teacher in Philosophy for Children", who serves as a coordinator, a moderator, and a facilitator. This concept of teacher, given its indirect and non-directorial action, seems to recall the teacher figure envisaged by Montessori: the "new teacher" - of course, always maintaining an asymmetrical role compared to the children - observes and offers his/her presence without being invasive or directorial.

\section{4 the new teacher and the teacher in $p 4 c$}

The environment thus set up and the independent (though not solitary) work of the children thus overcome the conventional role of the teacher, which manifests itself by subtraction and not by addition. The teacher, who doesn't dare to act as the only possessor of knowledge, has not so much the role of transmitting notions, but that to observe individual children, their relationships and - building on such relationships - set up an environment that is functional to the harmonic growth of children as a group and as individuals. The role of the teacher may be compared to that of a moderator, a facilitator that prepares the environment (as previously described) and serves as a vehicle to accompany every child in his/her discovery. A "new teacher", as suggested by Montessori, who rather than words, shall learn silence; rather than teaching, shall observe; rather than the proud dignity of a person who once wished to appear flawless, instead wears the drapes of humbleness and activates research processes. The teacher is thus mainly a channel that "puts the children in contact with their reagent".

Another innovation that has aroused much interest and controversy has been the role of the educator - the passive educator - who holds his own activities and authority in abeyance, lest they should be an obstacle preventing the child from acting for himself, and who is glad when he sees the child so acting, making progress on his own, and seeks no credit for it. He applies to himself the words of St. John the Baptist: 'He must increase: but I must decrease.' Another characteristic principle is respect for the child's personality, carried to a degree unattained in any other educational method (Montessori, 1996, 115). 
The environment, which is a resource for the community as well as the individual (but not solitary) work of boys and girls, overturns the canonical role of the teacher, which manifests itself and develops by subtraction, and not by addition. It would be truly superficial to view such attitude as a pure abstention, non-interference or non-action, in that the teacher is called to constantly intervene, though not directly.

Within the Community of Inquiry, teachers have the task to mediate and not to dominate. They configure themselves as "facilitators" of the research process. Their role is to accompany, follow, encourage dialogue and thought processes, and last but not least serve as mediators within a group; not only with the aim to resolve conflict themselves, but also to provide the tools for a nonviolent handling of the same by members of the Community of Inquiry. They are not static entities, but versatile and fast-moving actors ${ }^{3}$.

This type of teacher thus becomes, according to Walter Kohan, an "errant teacher". The author plays with the polysemy of the word "to err": to wander, to walk, but even to stumble, to make mistakes. The errant teacher thus makes mistakes, but at the same time does not fear them and does not interrupt his/her path. In line with Lipman's idea, the teacher errs and invents elements that may be linked to Socrates. In fact Socrates reinvents philosophy by means of the practice of questioning others so that they may precisely express the value of the life they live [...]. It is interesting to notice that Socrates does not refer to philosophy as something ready-made, known, concluded or legitimized, but as something done, practiced, experienced. (Kohan, 2014).

\footnotetext{
${ }^{3}$ Among theoretical references made by M. Santi (Santi, 2006), I hereby highlight C. Pontecorvo who has made a crucial contribution in identifying such roles. She defined them - in this context strictly for investigative and non-definitive purposes. In particular, she suggested an in-depth analysis of the research summarized in the text Discutendo s'impara - i.e. learning by debating (Pontecorvo, Ajello, Zucchermaglio 1999) - in which, starting from the importance of discussion and discussion with the other, the authors examine the theoretical principles of the discussion itself in depth. Throughout the text, it is highlighted how the situation of social interaction in the classroom - defined as a 'discussion' - implies language and social-cognitive processes that are particularly relevant for the purpose of acquiring new or more complex strategies and knowledge. In the social context of the classroom, the situation of discussion within a social-cognitive conflict activates new experimentation or cognitive operations that may subsequently be internalized as individual reasoning skills.
} 
possible connections between the montessori method and philosophy for children

The figure of the Teacher in Philosophy for Children and the new teacher proposed by Montessori mirrored that of Socrates, the son of a sculptor and a midwife. I like to think of the P4C Teacher's role (and even the teacher's role in general) as a blend of these two ancient professions: the sculptor, who - with his scalpel - has the courage to remove the excess marble preventing the figure to emerge, to show itself in its most authentic form (thus eliminating barriers or fraudulent help, including the interference of the adult, as Montessori would say); and the midwife, the obstetrician who, with her effort in "taking out" or "making come out" becomes a starting point, a launchpad and a point of reference, as she accompanies growth (with the "right help").

Lipman and Montessori have in common the image of a teacher that, miles away from the mere transmitter of notions, takes shape as a co-operator in the learning and thinking processes, encouraging the children to exercise an active role in the exchanges and encounters with their age group, with significant adults, with reality, and with the world: “...we shall give them great things: first of all, we shall give them the world" (Montessori, 1948).

This type of a teacher is a cooperator in learning processes and encourages children to play an active role in exchanges and interactions, whether in their age group, with their significant adults, or with reality. The teacher is a facilitator, a mediator that sets up heuristic occasions and, by means of observation or data collection, facilitates learning processes starting from the recognition of the children with their individual interests, questions, and challenges. Such leading figures will unavoidably be a professional who make reflexivity and deontology become categories of their own (see: Contini et al., 2014).

\section{4. conclusion}

Considering the framework of our age - which seems to highlight a context involving a high risk of widespread conflict and drenched with different levels of conditioning - even the most recent national (MIUR, 2012) and international policies (United Nations, 1989, art. 29; United Nations, 2015, Millennium Development Goals) underline the importance of envisaging an education 
targeted towards the promotion of complex thought, creative and nonviolent conflict resolution, and emotional expression: an education promoting ethical commitment in a cosmopolitan perspective. The legal framework mentions the right to think, from childhood. In the Italian context, purely by way of example, we shall refer to the 2012 national guidelines.

In such scenario, the school is intended to have certain specific purposes: to present occasions to apprehend basic cultural knowledge and languages to the students; to make it so that the students acquire the necessary thought tools to acknowledge and select information; to stimulate the students' ability to develop methods and categories that can serve as a compass to them in their personal pathway; to foster independent thinking in the students, directing the curricula towards the construction of knowledge, maintaining educational needs above all" (MIUR, 2012).

Although they re-focus on attention towards the right to exercise thought and to think together, the standards are written in a broad and non-central sense. Therefore, the choice is left to the freedom and common sense of certain teachers. In fact, even if the national guidelines refer to proposing active protagonism by the students, we may observe a substantial disconnection between such indications and everyday school praxis.

Schools present situations and contexts in which the students reflect in order to understand the world and themselves, they become aware that their body is an asset to care for, they find stimuli to develop analytical and complex thought, they learn to learn, they nurture fantasy and creative thought, they interact with each other to find different meanings and share possible patterns to understand reality, as they reflect on the sense and consequences of their choices.

Schools favor the development of the necessary abilities for students to learn how to read their own feelings and manage them, or to set themselves longterm goals and pursue them. Moreover, it promotes the primary sense of responsibility that translates to performing a task well and completing it, as well as caring for one's self, things, and environments experienced - both natural and social.

In terms of international law, I hereby outline two articles from the emblem of legal successes for childhood in the 1900s - the 1989 Convention on the Rights 
possible connections between the montessori method and philosophy for children

of the Child (United Nations, 1989). In Article 13, we read: "The child shall have the right to freedom of expression; this right shall include freedom to seek, receive and impart information and ideas of all kinds - regardless of frontiers - either orally, in writing or in print, in the form of art, or through any other media of the child's choice." References may also be found in article 14: "States Parties shall respect the right of the child to freedom of thought, conscience, and religion." And "States Parties shall respect the rights and duties of the parents and, when applicable, legal guardians, to provide direction to the child in the exercise of his or her right in a manner consistent with the evolving capacities of the child."

In a not-so-distant past, it has been extremely difficult to admit (and formalize) the rights and skills specific to children. It was only in 1989 that little boys and girls were officially considered individual bearers of their own rights.

Let us begin with a premise: children have always existed; childhood has not. Childhood is a social and cultural category, and as such exists only if it is recognized as a separate phase of life from the others, with its own peculiarities: in terms of needs, which one must respond to, but also in terms of skills. Historically, childhood hasn't always been given the recognition it deserves and requires.

I hereby call attention to the fact that, even to give value to the elements described thus far, MIUR ${ }^{4}$ has stipulated agreements with entities involved in promoting and developing the cultural heritage of the two education proposals. Such entities include Opera Nazionale Montessori ${ }^{5}$ and CRIF6. In the scope of the independence, academic institutions may, in fact, establish early childhood and elementary school sections based upon the Montessori differentiated teaching methods ever since the issuance (on February 16 ${ }^{\text {th }}, 1987$ ) of Italian Law $\mathrm{n}^{\circ} 46$ "Statizzazione delle sezioni di scuola materna e delle classi di scuola elementare

4 Italian Ministry of Education, University and Research. For further information, visit: https:/ / www.miur.gov.it/ (last consulted December 1st, 2017).

5 The Opera Nazionale Montessori (national Montessori institution) has been founded as a nonprofit organization following Italian Royal Decree $n^{\circ} 1534$ issued on August 8th $^{\text {th }}$ 1924, and has a legal status. For further information, visit: http://www.operanazionalemontessori.it/chisiamo/statuto.

${ }^{6}$ CRIF (Italian Research Center for Philosophical Inquiry) is acknowledged by the Institute for the Advancement of Philosophy for Children (IAPC), and is a member of the International Council for Philosophical Inquiry with Children (ICPIC). For further information, visit: http://www.filosofare.org/crif-p4c/. 
gestite dall'Opera nazionale Montessori" (Nationalization of early childhood and elementary school sections managed by Opera Nazionale Montessori), certified by MIUR. Such concession is granted exceptionally to the Montessori method, and implies that the related schools may even be public, and not just private or part of home-schooling programs.

Just like the Montessori method, P4C has also earned explicit and significant support from MIUR, which underlines - in its memorandum of understanding signed with CRIF (MIUR, 2017):

The national and international education system finds itself facing new challenges born out of the deep transformations of the society in which we live, with the need to integrate learning/teaching for the purpose of acquiring new knowledge with a more complex and significant educational mechanism targeted towards the achievement of cognitive and social-relational life skills both in the school environment and, more in general, in the lifelong learning context.

Such agreements - signed in response to both European and international indications, and to Italian legislative and ministerial decrees to promote actions in support of inclusive education and global citizenship - underline the effectiveness of the two education methods, in terms of setting, theoretical framework, and basic methodological setup. In particular, I believe that the common elements between the two authors identified in this paper are functional to the exercise of complex thought (in the broadest and narrowest sense of the term) and to the maturation of an efficient thought structure as a continuation of the idea of a "well-made head" (Morin, 2000).

In conclusion, upon recognizing children's right to exercise thought, we must identify the strategies to perform such action. Montessori and Lipman have studied children's thought experience, making significant contributions to different fields of education. The P4C proposal finds a rightful space within schools adopting the Montessori Method, and shows continuity with the concepts already existing in the daily academic setup.

The educational action may facilitate and amplify the existential repertoire in terms of thinking, acting, feeling, and knowing, as well as the relationship with others and with the most intimate facets of the self: the Montessori Method and 
possible connections between the montessori method and philosophy for children

Philosophy for Children walk, even together, towards this direction. Both in favor of the students, and in favor of the teachers. They provide an opportunity to raise awareness and reflect upon educational processes put in place, upon responsibility, and upon the power of the educational role even in terms of respecting children's rights, not least the right to think.

\section{references}

Contini, M., Demozzi, S., Fabbri, M., and Tolomelli, A. (2014), Deontologia pedagogica. Riflessività e pratiche di resistenza. Milano: Franco Angeli.

Dewey, J. (1916). Democracy and Education. An Introduction to the Philosophy of Education. London: Macmillan.

Goucha, M. (2007), Philosophy, a school of freedom: teaching philosophy and learning to philosophize; status and prospects, Paris: UNESCO.

Gregory M. R., and Laverty M. J. (2018). In community of inquiry with Ann Margaret Sharp. London: Childhood, philosophy and education, Routledge.

Gregory, M. R. (2004). "Practicing democracy: Social intelligence and philosophical practice". International Journal of Applied Philosophy, 18(2): 163-176.

Kohan, W. O. (2015). Childhood, education, and philosophy: new ideas for an old relationship. London New York: Routledge

Kohan, W. O., Santi, M., and Wozniak, J. T. (2016). Between ignorance, invention and improvisation. The Routledge International Handbook of Philosophy for Children, 253.

Maughn Rollins, G. (2007). Normative dialogue types in philosophy for children. Gifted Education International, 22(2-3): 160-171.

Maughn Rollins, Gregory (2011). Philosophy for Children and its Critics: A Mendham Dialogue. Journal of Philosophy of Education, Vol. 45 (2): 199-219.

Kennedy, D. (2004). The role of a facilitator in a community of philosophical inquiry. Metaphilosophy, 35(5): 744-765.

Lipman, M. (1995). Moral Education higher-order Thinking and Philosophy for Children. Amsterdam: Early Child Development and Care 107: 61-70, Overseas Publishers Association.

Lipman, M. (2003 [199) Thinking in education. New York: Cambridge University Press, 2nd edition.

Lipman, M. (2008). A Life Teaching Thinking. New York: IAPC, Montclair.

MIUR (2012). Italian Curriculum National Guidelines (Indicazioni nazionali per il curricolo della scuola dell'infanzia e del primo ciclo di istruzione). Decreto Ministeriale $\mathrm{n}^{\circ} 254$ del 16/11/2012. Gazzetta Ufficale n. 30 del 05/02/2013. Available at: http://www.indicazioninazionali.it

MIUR (2017). Memorandum of Understanding between MIUR and CRIF. La pratica filosofica come opportunità di apprendimento per tutti (philosophical practice as a learning opportunity for all).

URL: http://www.filosofare.org/crif-p4c/protocollo-dintesa-miur-crif/ (last consulted December 1st, 2017).

Montessori, M. (1964) The Montessori method. New York: Schocken Books, Inc.

Montessori, M. (1967). The discovery of the child. New York: Fides Publisher Inc.

Montessori, M. (1996). The Secret of Childhood. Chennai: Orient Longman. 
Montessori M., (2000). Il bambino in famiglia (The Child in the Family - Italian edition). Milano: Garzanti, 2000

Montessori, M. (2016). Dall'infanzia all'adolescenza (From Childhood to Adolescence). Roma: Franco Angeli.

Morin E. (2000), La testa ben fatta, Riforma dell'insegnamento e riforma del pensiero nel tempo della globalizzazione (The head well made, Reform of teaching and reform of thought in the time of globalization), Milano: Raffaello Cortina.

Pontecorvo, C. Ajello, A. M., Zucchermaglio, C., (1999 [1991]). Discutendo si impara, Roma: Carocci.

Regni, R. (2006) Il bambino filosofo e il segreto dell'infanzia: una prospettiva montessoriana (The Child-Philosopher and the Secret of Childhood: A Montessorian Perspective), in L. Rossetti, C. Chiapperini (edited by); Filosofare con $i$ bambini e i ragazzi. Atti delle giornate di studio di Villa Montesca (Philosophizing with Children and Young Adults. Notes from the Villa Montesca EWorkshop). Perugia: Malocchi Editore.

Rilke R. M. (1989), Lettere a un giovane poeta (Letters to a young poet), Milano: Adelphi.

Santi M. (2006) Costruire comunità di integrazione in classe. Lecce: Ed. Pensa Multimedia.

Santi M., Zorzi E. (2016), Education as Jazz, Cambridge Scholars Publishing, Newcastle upon Tyne.

Sharp, A. M. (1991).The community of inquiry: Education for democracy. Thinking in education. The journal of philosophy for children, 9(2), 31-37, 1991.

Sharp, A. M. (1987). What is a "Community of Inquiry"? Journal of Moral Education, 16(1): $37-45$.

United Nations (1989), General Assembly resolution 44/25. Convention on the Rights of the Child.

URL: https://www.ohchr.org/en/professionalinterest/pages/crc.aspx

United Nations (2015). Transforming our World. The 2030 Agenda for Sustainable Development.

URL:

https:// sustainabledevelopment.un.org/content/documents/21252030\%20Agend a\%20for\%20Sustainable\%20Development\%20web.pdf

Weinstein, J. (2016). A Safe Creativity Environment. In M. Santi, E. Zorzi (ed. by), Education as Jazz. Interdisciplinary Sketches on a New Metaphor. Newcastle upon Tyne: Cambridge Scholars.

received in: 19.11.2019

approved in: 08.03.2020 